\title{
Patterns of forest dynamics in a secondary old-growth beech-dominated forest in the Jizera Mountains Beech Forest Reserve, Czech Republic
}

\author{
Jana Lábusová ${ }^{(1)}$, \\ Robert C Morrissey ${ }^{(1)}$, \\ Volodymyr Trotsiuk ${ }^{(1-2-3)}$, \\ Pavel Janda ${ }^{(1)}$, \\ Radek Bače ${ }^{(1)}$, \\ Vojtech Cada ${ }^{(1)}$, \\ Martin Mikoláś ${ }^{(1-4)}$, \\ Hana Mrhalová (1), \\ Jonathan S Schurman (1), \\ Kristýna Svobodová ${ }^{(1-5)}$, \\ Lenka Mateju ${ }^{(1)}$, \\ Michal Synek ${ }^{(1)}$, \\ Miroslav Svoboda ${ }^{(1)}$
}

\begin{abstract}
Restoring the structural characteristics of secondary old-growth forests that were previously managed is increasingly debated to help increase the area of more complex forests which provide a broader array of forest services and functions. The paucity of long-term data sets in Central Europe has limited our ability to understand the ongoing ecological processes required for effective restoration programs for old-growth forests. To address this, we used repeated census data from eight permanent plots to evaluate forest structural dynamics over a 12-year period in the largest complex of European beech (Fagus sylvatica L.) forests in the Czech Highlands without intensive forestry intervention for almost $\mathbf{5 0}$ years. Our results showed that previously managed forests can exhibit structural qualities typically associated with old-growth forests after management has ceased for a period. The stand structural characteristics (e.g., density of large and old trees) is comparable with protected reserves of old-growth European beech-dominated forests. The average stand age was 196 years, but the oldest tree was 289 years old. The annual mortality rate was $0.43 \%$ for all species, and the U-shaped distribution indicating size-dependent mortality is likely an important process that is balanced by the turnover of new tree recruitment. During the study period, we detected that the diameter distribution tended towards a rotated sigmoid distribution. The lasting effects of the most recent forest management are evident in the scarcity of dead wood, and a prolonged process of dead wood accumulation has begun. Thus, the abandonment of all management activities in near-natural forest reserves, including dead wood removal, will ensure that the forests will develop characteristics typical of old-growth forests.
\end{abstract}

Keywords: Dead Wood, Diameter Distribution, Fagus sylvatica, Forest Reserve, Forest Structure, Mortality, Old-growth Forest large and old trees, standing dead trees, and large amounts of lying dead wood (Bauhus et al. 2009). Tree diameter distribution is also a representative structural feature often used to describe old-growth forests (Leak 1964). The reverse J-shaped form has traditionally been considered indicative of old-growth forests in a state of equilibrium (Meyer 1952, Leak 1964, Can-
(1) Czech University of Life Sciences Prague, Faculty of Forestry and Wood Sciences, Kamyěckaě 129, Praha 6, Suchdol 16521 (Czech Republic); (2) Swiss Federal Institute for Forest, Snow and Landscape Research WSL, Zuercherstrasse 111, 8903 Birmensdorf (Switzerland); (3) ETH Zurich, Department of Environmental Systems Science, Institute of Agricultural Sciences, 8092 Zurich (Switzerland); (4) PRALES, o.z., Odtrnovie 563, Rosina, 03122 (Slovakia); (5) Faculty of Environmental Sciences, Czech University of Life Sciences Prague, Kamýcká 129, Prague 6, 16521 (Czech Republic)

@ Jana Lábusová (labusova@fld.czu.cz)

Received: Nov 30, 2017 - Accepted: Oct 26, 2018

Citation: Lábusová J, Morrissey RC, Trotsiuk V, Janda P, Bače R, Cada V, Mikoláš M, Mrhalová H, Schurman JS, Svobodová K, Mateju L, Synek M, Svoboda M (2019). Patterns of forest dynamics in a secondary old-growth beech-dominated forest in the Jizera Mountains Beech Forest Reserve, Czech Republic. iForest 12: 17-26. - doi: 10.3832/ifor2702-011 [online 201901-10]

Communicated by: Gianluca Piovesan cino \& Von Gadow 2002), a condition maintained by equal mortality rates among diameter classes across the entire range of diameters (Westphal et al. 2006). However, other studies have indicated that other forms of diameter distributions, such as a rotated sigmoid curve (Goff \& West 1975, Lorimer et al. 2001, Alessandrini et al. 2011), could also be characteristic of oldgrowth forests. A rotated sigmoid develops from rapid growth and low mortality in trees in the mid-range diameter classes sizes, which illustrates a U-shaped mortality distribution (Lorimer et al. 2001). Effective restoration programs require a thorough understanding of forest structure. Old-growth attributes (i.e., functional and structural features associated with oldgrowth forests) develop naturally over time, but appropriate forest management can also facilitate their development (Bauhus et al. 2009). Active restoration entails the implementation of various management techniques, such as planting seedlings, girdling, or thinning, and passive restoration describes a situation in which no action is taken except to reduce environmental stressors, such as dead wood removals or harvesting. There is vigorous debate as to which management strategy is 


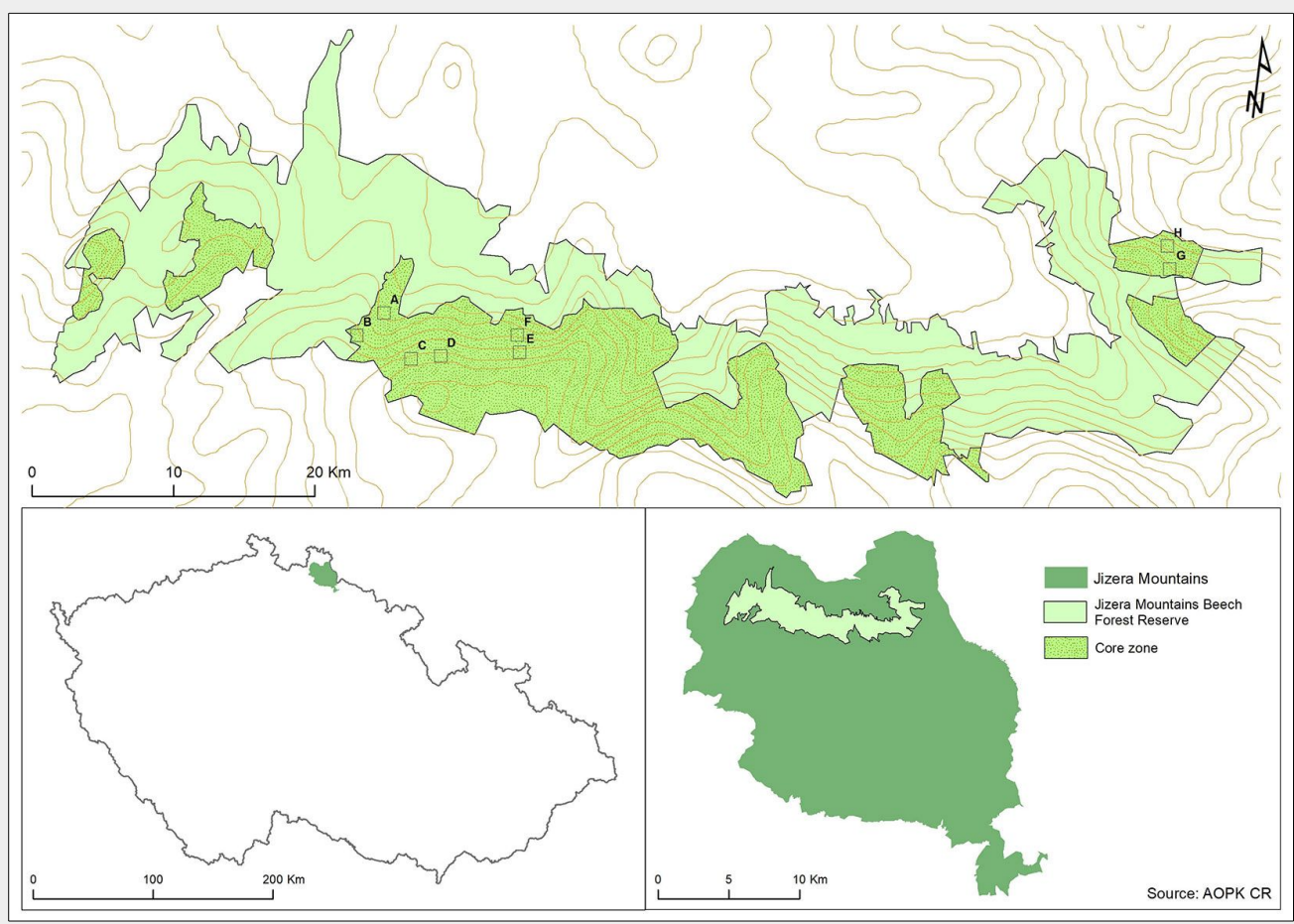

Fig. 1 - Location of the research area in Czech Republic (Jizera Mountains Beech Forest).

Reserve and core zones in the reserve. Empty squares represent the study plots $(A-H)$.

most suitable to implement the development of old-growth attributes. Recent studies suggest that active restoration of old-growth attributes provides alternatives to conventional even- and uneven-aged silvicultural practices (Keeton 2006, Dove \& Keeton 2015); however, such approaches (e.g., generating snags by girdling diseased or dying trees, cutting to a rotated sigmoid diameter distribution, and downing logs by pulling or pushing trees over) are expensive. Alternatively, passive restoration should be considered when the restoration process can be expected to achieve the desired forest structure within a feasible time period (Lachat \& Bütler 2009).

In Central Europe, mountain areas constitute some of the largest remnants of primary forests that have survived well into modern times (Holeksa et al. 2009, Veen et al. 2010). Because of their inaccessibility, most were not managed until the nineteenth century. Improvements in transportation and increasing wood fuel demands for industry increased the accessibility and value of untouched forests. However, even in remote mountainous areas, the possibility of centuries of selective logging, grazing, or charcoal burning can be recognized (Peterken 1996). Large aristocratic and monastic hunting estates of the past have contributed to the protection of many untouched forests. Nowadays, forest reserves under varying protection regimes account for only $12 \%$ of the European forest area (Parviainen et al. 2011). Although the protected area network has increased substantially in the last few decades, many allow large-scale harvesting inside their boundaries and numerous areas have been illegally harvested (Knorn et al. 2012, Vysoky \& Jasík 2015). Thus, the concepts and strategies that integrate forest habitat re- quirements into the management and production of other forest goods and services are mandatory for sustainable forest management and the preservation of forest biodiversity in landscape ecosystems (Bauhus et al. 2009, Persiani et al. 2015).

In the Czech Republic, conservation programs protecting forest reserves have increasingly used passive restoration methods since 2002. More than 2,000 ha of forest areas have been entirely excluded from any forest management, but that corresponds to only $0.83 \%$ of all forests in the Czech Republic (Vrška \& Hort 2008). These protected forest areas are still very small and generally consist of smaller, isolated patches, as is common in most European countries (Parviainen et al. 2000). One of those unmanaged forests is located in the Jizera Mountains Beech Forest Reserve, the largest continuous European beech (Fagus sylvatica L.) forest complex in the Czech Highlands. This area provides a unique perspective on forest changes after the implementation of passive management. However, it is uncertain how quickly forest structural complexity will change and how the transition to old-growth status will develop afterwards. As a result of climate change, accelerating rates of change in structure, composition, and mortality have been reported worldwide (Allen et al. 2015). Quantifying the patterns and processes in developing forests is essential for conserving biodiversity and ecosystem services. We employed repeated census plot data to quantify changes in forest structure and mortality after the cessation of active forest management, and we addressed the following questions: (i) what is the current stand structure of forests in the Jizera Mountains Beech Forest Reserve after the cessation of management? Does it already have some old-growth attributes? How do selected structural characteristics compare to those of primary oldgrowth forests? (ii) How much have the selected structural characteristics changed over a 12-year study period? What are the rates of mortality and new tree recruitment? What are the size-mortality trends within the nature reserve? How has diameter distribution changed during the studied period?

\section{Methods}

\section{Study area}

The study area is located in the Jizera Mountains (Jizerské hory) within the Jizera Mountains Beech Forest Reserve (Jizerskohorské bučiny), Czech Republic (Fig. 1). The reserve is situated on the northern slopes along an altitudinal gradient ranging from 360 to $1006 \mathrm{~m}$ a.s.l. The climate is very humid because the Jizera Mountains are the first transcontinental barrier of the humid oceanic flow from the North Sea. Annual rainfall averages range between 800 and $1700 \mathrm{~mm}$ and the growing season lasts from 110 to 160 days (Tolasz et al. 2007). The average annual temperatures, which are strongly related to altitude, range from 3 to $7.5^{\circ} \mathrm{C}$. The uniform bedrock consists of a significant proportion of porphyric biotite granite to granodiorite, and the northwestern portion is composed of coarse-grained porphyric biotite granite. Cambisols and podzols, the most common soils in the reserve, are strongly acidic and have high contents of poor quality humus with highly variable depth profiles (Zatloukal et al. 2010).

\section{Land use history}

We have records of at least 200 years of 
selective logging in the reserve prior to 1960, after which the most preserved sites of beech-dominated forests representative of the old-growth attributes were protected in small, dispersed reserves. In 1999, these isolated reserves became the core zones of a single protected area $27 \mathrm{~km}^{2}$ in size connected with buffer zones. Since 1960 , soft active management, including selective logging, dead wood removal, banding trees, and also plantations in some portions, was conducted throughout the buffer zones; however, the $9.5 \mathrm{~km}^{2}$ of dispersed core zones were allowed to develop naturally without any management and spontaneous forest development persisted.

Natural vegetation includes mainly mountain acidic beech-dominated forests and small areas of high-elevation spruce forests. The main tree species in the reserve are F. sylvatica (79\%) and Picea abies (L.) Karst. (13\%). Acer pseudoplatanus L. (2.8\%), Sorbus aucuparia L. (2.2\%), and Betula pendula Roth (1.2\%) are admixed throughout, and a few species, such as Larix decidua Mill. (0.64\%), Fraxinus excelsior L. (0.19\%), Abies alba Mill. (0.08\%), and Acer platanoides L. (0.01\%), occur only rarely (Zatloukal et al. 2010).

\section{Data collection}

In 2003 , eight $50 \times 50 \mathrm{~m}$ permanent research plots were established at the forest reserve within the core zones (Fig. 1), a minimum distance of $50 \mathrm{~m}$ was maintained between all plots and any core zone edges. Plots were selected based on site conditions observed in the field in a part of the reserve comprised entirely of the most well-preserved sites that were allowed to develop naturally without any extensive forest management. The plot locations were selected to reflect more complex cover textures and forest structural variability (Trešnák 2004). A description of the study plots is reported in Tab. 1 . Species, diameter at breast height (DBH), status based on Kraft classification (Assmann 1961), and height were recorded for all living trees $\geq 5 \mathrm{~cm} \mathrm{DBH}$. All trees, dead wood, and rocks were mapped using a compass and diameter tape. When plots were remeasured in 2015, DBH, height, and status were recorded for all trees $\geq 5 \mathrm{~cm} \mathrm{DBH}$ and $\geq 20 \mathrm{~cm}$ tall, as well as for standing dead trees, including snags and stumps. Dead trees were defined as being physiologically dead if the crown had been completely destroyed or if the tree was completely uprooted and dead. Lying dead wood tallied included portions of trunks and large branches with a minimum length of $1 \mathrm{~m}$ and a minimum diameter of $6 \mathrm{~cm}$. Spatial location of all trees and dead wood were recorded with Field-Map electronic and laser measuring devices linked to GIS (IFER 2008). Topographic attributes, including slope, aspect, and altitude, were recorded for all plots (Tab. 1). For a random subsample of trees, a single increment core at breast height $(1.3 \mathrm{~m})$ was extracted from living trees $\geq 5 \mathrm{~cm} \mathrm{DBH}(n=85)$ of different tree species (F. sylvatica, $\mathrm{n}=77$; Acer spp., $\mathrm{n}$ = 5; P. abies, $\mathrm{n}=2$; $S$. aucuparia, $\mathrm{n}=1$ ). The number of cores on each plot varied depending on the live tree density.

\section{Data processing}

Increment cores were dried, cut with a core microtome, and secured on wooden mounts. The widths of the growth rings were measured according to standard dendrochronological analysis (Stokes \& Smiley 1986) using TSAP-Win software (Rinntech 2010) and verified with CDendro software (Cybis 2014) software. We used increment cores that included or were close to the pith: $33 \%$ of all cores included the pith, $25 \%$ were within $0.5 \mathrm{~cm}$ of the pith, $29 \%$ were within $2 \mathrm{~cm}$ of the pith, and $13 \%$ were within $10 \mathrm{~cm}$ of the pith. The age at breast height of trees with complete cores was estimated based on the crossdated tree ring series. To determine the age of trees without the pith, a standard graphical method was applied (Duncan 1989). Only one sample did not cross-date well, and it was excluded from all further analyses.

\section{Data analyses}

We calculated density, basal area, mean diameter, standard deviation of diameter, species composition by basal area, and density of large trees with $\mathrm{DBH}>50 \mathrm{~cm}$ and $>80 \mathrm{~cm}$. Volume of living trees and standing dead trees was calculated using two-parameter (DBH and height) equations derived by Petráš \& Pajtík (1991). Lying dead wood volume was evaluated using Field-Map software (IFER 2008). The decay stage was assessed according to Sippola \& Renvall (1999), whereby decay was primarily based on the depth of penetration of an iron spike. As indicators of spatial indices of structural diversity, we calculated the coefficient of variation and Gini coefficient based on basal area to characterize inequity in the size distribution among living trees (Gini 1921). Annual mortality, $m$, was calculated based on the 12year study period (Sheil \& May 1996):

$$
m=100 \cdot\left[1-\left(\frac{N_{t}}{N_{0}}\right)^{\frac{1}{t}}\right]
$$

where $N_{0}$ and $N_{t}$ are the numbers of living trees at the beginning and at the end of

Tab. 1 - Characteristics of the study plots (A-H).

\begin{tabular}{ccccc}
\hline Plot & $\begin{array}{c}\text { Area } \\
\text { (ha) }\end{array}$ & $\begin{array}{c}\text { Altitude } \\
(\mathbf{m} \text { a.s.l.) }\end{array}$ & $\begin{array}{c}\text { Slope } \\
\left({ }^{\circ}\right)\end{array}$ & Aspect \\
\hline A & 0.30 & 590 & 35 & E \\
\hline B & 0.25 & 680 & 30 & W \\
C & 0.25 & 610 & 35 & N \\
\hline D & 0.25 & 690 & 24 & NW \\
\hline E & 0.25 & 700 & 25 & NW \\
\hline F & 0.25 & 580 & 22 & $\mathrm{NW}$ \\
\hline G & 0.25 & 680 & 30 & $\mathrm{~S}$ \\
\hline H & 0.25 & 840 & 40 & $\mathrm{~S}$ \\
\hline
\end{tabular}

the interval, respectively, and $t$ is the inventory interval in years. The mortality within size classes was evaluated for five classes (5-9.9 cm, 10-29.9 cm, 30-49.9 cm, 50-69.9 $\mathrm{cm}$, and $\geq 70 \mathrm{~cm} \mathrm{DBH}$ ). To account for tree recruitment, new trees 5 to $20 \mathrm{~cm} \mathrm{DBH}$ were measured during the 2015 inventory. Mean age of the oldest tree of each plot was estimated as an average of the five oldest trees on the plot. Tree recruitment patterns were visually explored using age distribution at the landscape level. The third-degree polynomial function was used to describe the age-diameter relationship of F. sylvatica $(n=76)$; relationships for other species were only visually explored. The diameter distribution of living trees was analyzed by fitting a nonparametric kernel estimation and third-degree polynomial function; temporal changes in the diameter distributions of living trees between inventories were also tested using a Kolmogorov-Smirnov test. Finally, our results were compared with other studies from old-growth European beech-dominated forest reserves. Relevant publications were identified by searching the online database of Web of Science using the following search terms: Fagus, structure or structural, old-growth or virgin or primary. After applying the search filters, a total of nine articles were identified that reported structural biometrics directly relevant to our analyses and were located within Europe. For further comparison, the mean values of our selected variables were computed from a review of European beechdominated forests by Burrascano et al. (2013). All calculations were performed using $R$ statistical software (RStudio Team 2016).

\section{Results}

\section{Current forest structure}

An overview of structural characteristics is presented in Tab. 2. Across all study plots, F. sylvatica was the dominant tree species; it accounted for at least $85 \%$ of the basal area on all plots, and some plots contained only F. sylvatica. Among standing dead trees, F. sylvatica was also the dominant species $(53 \%$ to $100 \%$ of the basal area), with the exception of one plot, where $P$. abies represented $53 \%$ of the basal area (Tab. 2). Tree density and basal area 
Tab. 2 - Structural characteristics of the study plots (A-H). (1): Average value for all study plots; (2): trees with DBH $\geq 50 \mathrm{~cm}$; (3): trees with $\mathrm{DBH} \geq 80 \mathrm{~cm}$; (4): mean age of five oldest trees in the plot; (5): age of the oldest tree in then plot (all oldest trees were F. sylvatica).

\begin{tabular}{|c|c|c|c|c|c|c|c|c|c|c|c|}
\hline \multirow{2}{*}{ Variable } & \multirow{2}{*}{$\begin{array}{l}\text { Status/ } \\
\text { Stats }\end{array}$} & \multirow{2}{*}{ Year } & \multicolumn{8}{|c|}{ Plots } & \multirow{2}{*}{$\operatorname{Avg}{ }^{(1)}$} \\
\hline & & & A & B & C & D & $E$ & $F$ & G & $\mathrm{H}$ & \\
\hline \multirow{2}{*}{$\begin{array}{l}\text { Percentage of } \\
\text { Fagus sylvatica (\%) }\end{array}$} & Living & \multirow{2}{*}{2015} & 100 & 92 & 85 & 100 & 97 & 100 & 90 & 91 & 94 \\
\hline & Dead & & 62 & 86 & 77 & 100 & 53 & 100 & 47 & 71 & 75 \\
\hline \multirow{3}{*}{$\begin{array}{l}\text { Mean Diameter } \\
(\mathrm{cm})\end{array}$} & \multirow{2}{*}{ Living } & 2003 & 48.8 & 61 & 21.6 & 48.1 & 55.7 & 50 & 49.8 & 39.7 & 46.8 \\
\hline & & 2015 & 50.4 & 49.7 & 20.5 & 44.5 & 43.3 & 50.9 & 49.8 & 39.7 & 43.6 \\
\hline & Dead & 2015 & 29.3 & 61 & 46.4 & 58.6 & 43.3 & 38.6 & 40.5 & 51.5 & 46.2 \\
\hline \multirow{3}{*}{$\begin{array}{l}\text { STD Diameter } \\
(\mathrm{cm})\end{array}$} & \multirow{2}{*}{ Living } & 2003 & 14.5 & 17.1 & 21.2 & 27.7 & 17.5 & 25.5 & 28.4 & 18 & 21.2 \\
\hline & & 2015 & 15.7 & 28.9 & 19.2 & 31.7 & 28.7 & 27.6 & 27.1 & 18.3 & 24.7 \\
\hline & Dead & 2015 & 14.3 & 17.9 & 28.7 & 24 & 15.7 & 5.4 & 22.1 & 25.9 & 19.3 \\
\hline \multirow{3}{*}{$\begin{array}{l}\text { Basal area } \\
\left(\mathrm{m}^{2} \mathrm{ha}^{-1}\right)\end{array}$} & \multirow{2}{*}{ Living } & 2003 & 29.8 & 33.9 & 31.3 & 36.5 & 29.9 & 40.4 & 40.1 & 29.8 & 34 \\
\hline & & 2015 & 32 & 35 & 29.9 & 39.9 & 32.8 & 42.9 & 38.2 & 32.9 & 35.5 \\
\hline & Dead & 2015 & 1.8 & 5.9 & 9.3 & 6.5 & 1.1 & 0.8 & 6.5 & 7.1 & 4.9 \\
\hline \multirow{3}{*}{$\begin{array}{l}\text { Stem density } \\
\left(\text { inds } \mathrm{ha}^{-1} \text { ) }\right.\end{array}$} & \multirow{2}{*}{ Living } & 2003 & 147 & 108 & 436 & 152 & 112 & 164 & 156 & 200 & 184 \\
\hline & & 2015 & 147 & 136 & 484 & 172 & 156 & 164 & 152 & 220 & 204 \\
\hline & Dead & 2015 & 20 & 16 & 28 & 20 & 4 & 8 & 36 & 28 & 20 \\
\hline \multirow{3}{*}{$\begin{array}{l}\text { Large trees } 50^{(2)} \\
\text { (inds ha-1 }^{-1} \text { ) }\end{array}$} & \multirow{2}{*}{ Living } & 2003 & 83 & 80 & 52 & 72 & 80 & 80 & 68 & 48 & 70 \\
\hline & & 2015 & 80 & 76 & 48 & 80 & 80 & 84 & 68 & 56 & 72 \\
\hline & Dead & 2015 & 7 & 16 & 24 & 24 & 8 & 0 & 16 & 16 & 14 \\
\hline \multirow{3}{*}{$\begin{array}{l}\text { Large trees } 80^{(3)} \\
\text { (inds ha-1) }\end{array}$} & \multirow{2}{*}{ Living } & 2003 & 0 & 20 & 12 & 20 & 4 & 20 & 20 & 4 & 13 \\
\hline & & 2015 & 0 & 20 & 16 & 32 & 4 & 32 & 20 & 8 & 17 \\
\hline & Dead & 2015 & 0 & 4 & 8 & 8 & 0 & 0 & 4 & 4 & 4 \\
\hline \multirow{2}{*}{$\begin{array}{l}\text { Age } \\
\text { (years) }\end{array}$} & Mean ${ }^{(4)}$ & \multirow{2}{*}{2015} & 205 & 198 & 167 & 212 & 205 & 257 & 153 & 171 & 196 \\
\hline & $\operatorname{Max}^{(5)}$ & & 252 & 237 & 236 & 220 & 242 & 289 & 160 & 173 & 234 \\
\hline
\end{tabular}
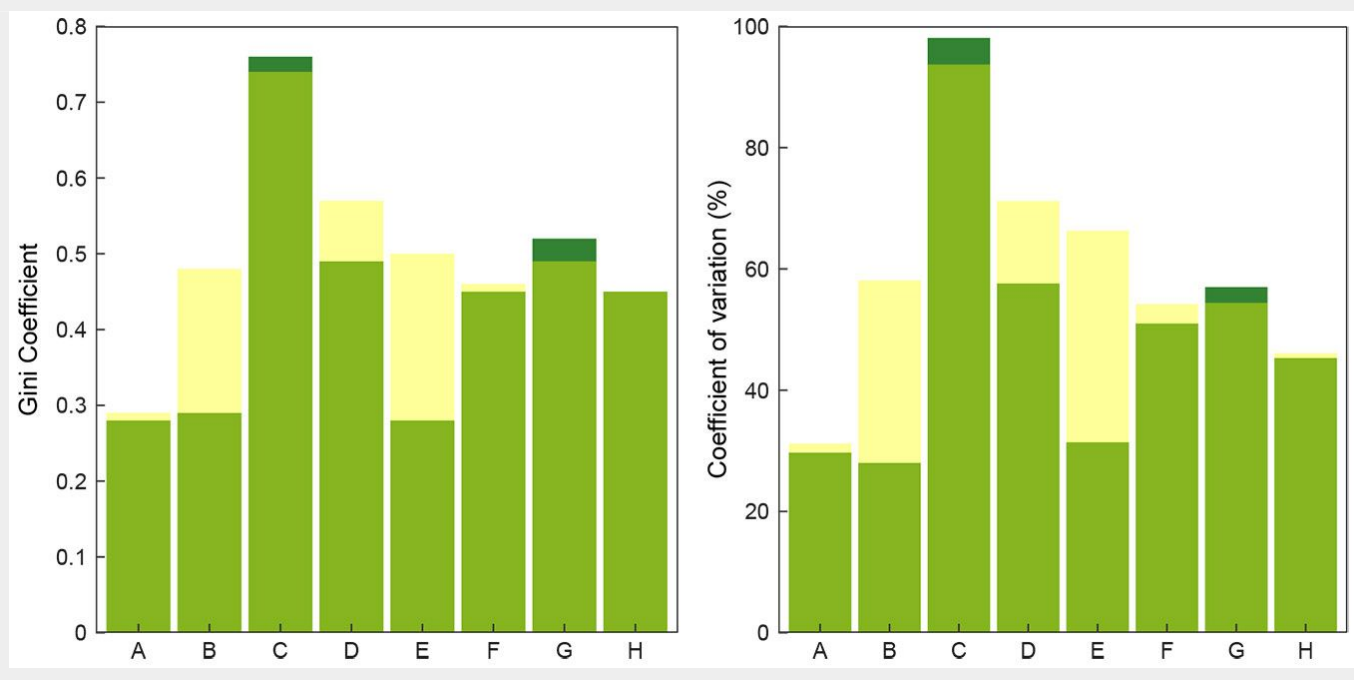

Fig. 2 - Structural diversity indices. Gini coefficient (left panel) and coefficient of variation of tree diameters (right panel) indices characterizing the study plots (A-H) in 2003 (green) and 2015 (yellow). Dark green indicates a decrease of the index value during the study period.

varied greatly among plots. The mean tree atively high mean DBH of living trees, with density was 204 trees ha-1 and 20 trees ha-1 the exception of plot C, but the mean DBH for living and standing dead trees, respec- of standing dead trees was slightly greater tively. On average, basal area was $35.5 \mathrm{~m}^{2}$ (Tab. 2). Frequency of large trees with DBH ha ${ }^{-1}$ and $4.9 \mathrm{~m}^{2} \mathrm{ha}^{-1}$ for living and standing $\geq 50 \mathrm{~cm}$ was relatively high in all plots (Tab. dead trees, respectively. Plots all had a rel- 2). Density of larger living trees with DBH $\geq$

Tab. 3 - Summary of dead wood volume on study plots (A-H) in 2015.

\begin{tabular}{llrrrrrrrrr}
\hline Variable & Status & A & B & C & D & E & F & G & H & Avg \\
\hline Volume & Living & 494 & 520 & 433 & 716 & 534 & 726 & 649 & 391 & 558 \\
$\left(\mathrm{~m}^{3}\right.$ ha $\left.^{-1}\right)$ & Standing dead & 7 & 16 & 55 & 4 & 5 & 7 & 83 & 82 & 32 \\
& Lying dead wood & 46 & 36 & 46 & 38 & 23 & 16 & 34 & 51 & 36 \\
& Total dead wood & 53 & 52 & 101 & 42 & 28 & 23 & 117 & 133 & 69 \\
& 11 & 10 & 23 & 6 & 5 & 3 & 18 & 34 & 14 \\
\hline Dead wood/ living ratio (\%) & 13 & 31 & 54 & 10 & 18 & 30 & 71 & 62 & 36 \\
\hline St. dead/ dead wood ratio (\%) & 13 & & & & & & & & &
\end{tabular}




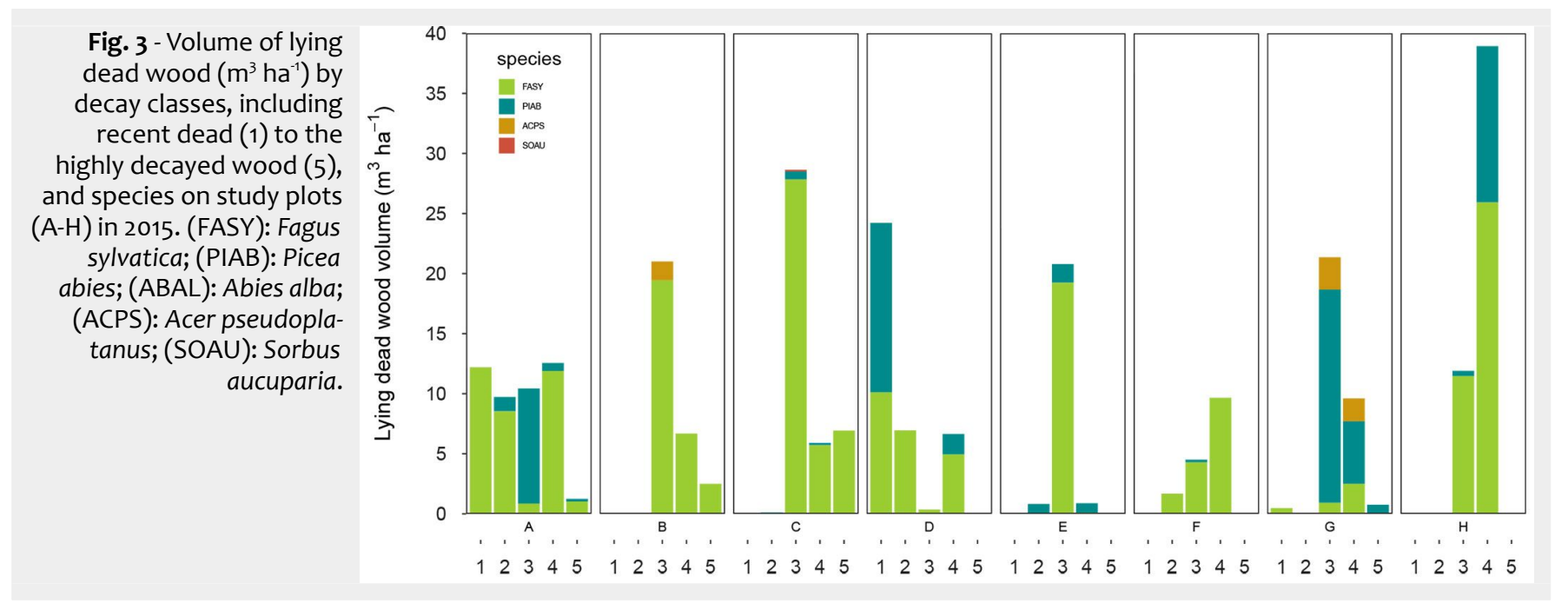

of the total volume of lying dead wood. The most common species among lying dead wood was F. sylvatica; the contribution of other tree species was negligible (Fig. 3).

The oldest tree was a 289-year old F. sylvatica (on plot $F$ ). The maximum age of $A$. pseudoplatanus and $P$. abies was estimated to be 165 and 153 years old, respectively. The average of the mean plot ages was 196 years, with a range of 153 to 257 years (Tab. 2). Tree establishment occurred irregularly throughout the last three centuries. There were four peaks observed around 1770, 1800-1810, 1850-1870, and 1960 (see Fig. S1 in Supplementary material), and relatively long periods of four decades or more with little tree establishment. The evaluation of the relationship between tree age and diameter among $F$. sylvatica was best described by a third polynomial regression ( $\mathrm{n}$ $=77, R^{2}=0.698-$ Fig. 4 ).

\section{Changes in forest structural characteristics}

The most variable stand characteristic over time was the density of large trees $\geq$ $80 \mathrm{~cm} \mathrm{DBH}$ with a mean increase of $32.0 \%$ (Tab. 2). Other structural attributes were much less variable over time; value increases were $+10.6 \%$ for stem density, $+4.4 \%$ for basal area, and $+1.6 \%$ for density of large trees $>50 \mathrm{~cm}$ DBH. Standard deviation of diameter displayed a relatively sustained increase of $16.1 \%$. No major changes in species composition were observed between the two measurements. Changes in the structural diversity indices varied greatly among study plots, whereas the overall mean increase was $13.1 \%$ for the coefficient of variation and $19.4 \%$ for the Gini coefficient (Fig. 2). The highest change of structural indices was observed on plot $\mathrm{E}$. The size-mortality trend was asymmetrically $\mathrm{U}$ shaped for all study sites. Annual mortality rates declined from about $0.3 \%$ in the smallest diameter class to $0.1 \%$ in the $20-\mathrm{cm}$ class, and then it increased to about $0.8 \%$ in classes $\geq 70 \mathrm{~cm}$ DBH (Fig. 5). During the 12year study period, the overall mortality rate was $0.43 \%$ year $^{-1}$ (19 dead of 376 living and two trees had a broken stem, but they trees in 2003 - see Tab. S1 in Supplemen- were still alive. The highest mortality rate tary material). Three trees were uprooted, was observed on plot B $\left(0.64 \%\right.$ year $\left.^{-1}\right)$, and

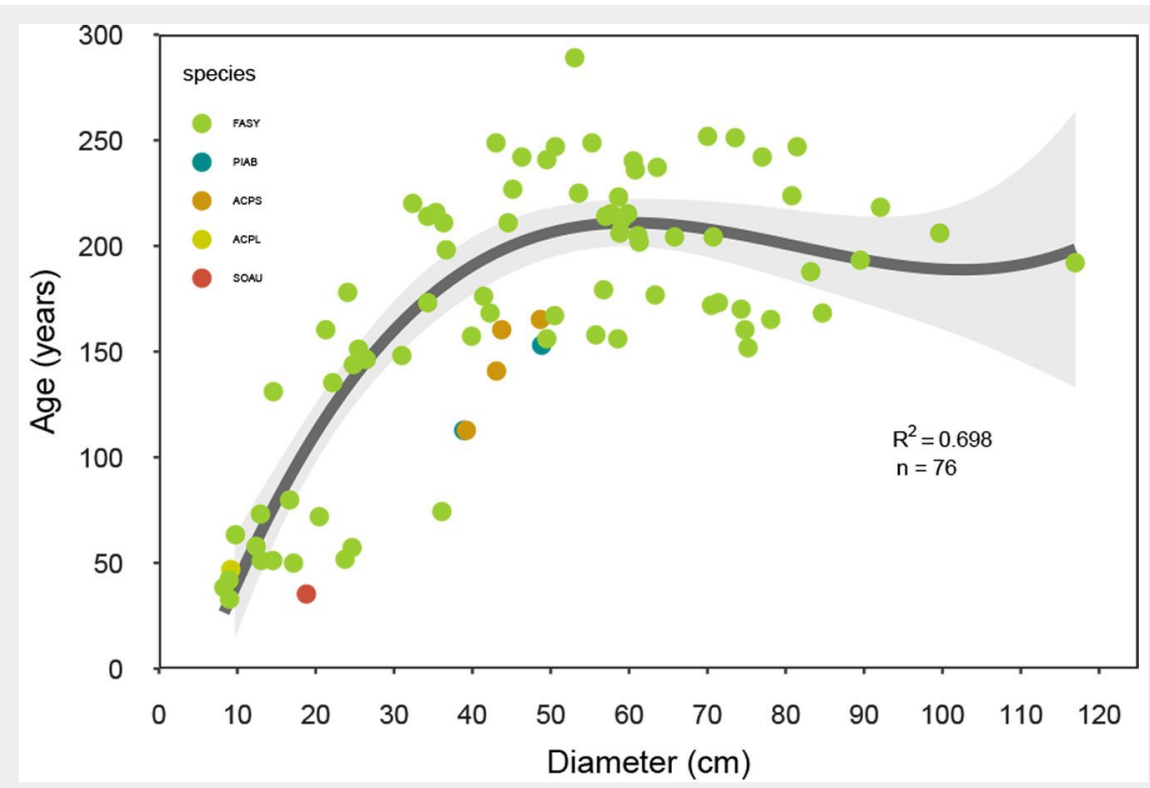

Fig. 4 - Relationship between tree age and tree diameter from all study sites. Loess curve with the $95 \%$ confidence interval is reported for the relationship of Fagus sylvatica species. (FASY): Fagus sylvatica; (PIAB): Picea abies; (ACPS): Acer pseudoplatanus; (ACPL): Acer platanoides; (SOAU): Sorbus aucuparia.

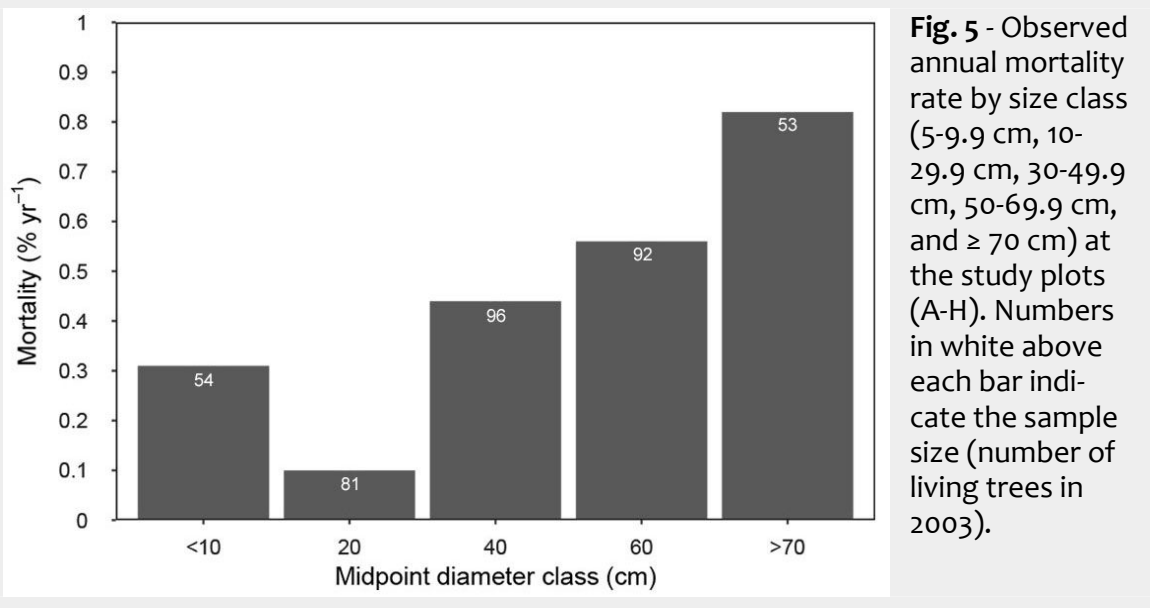




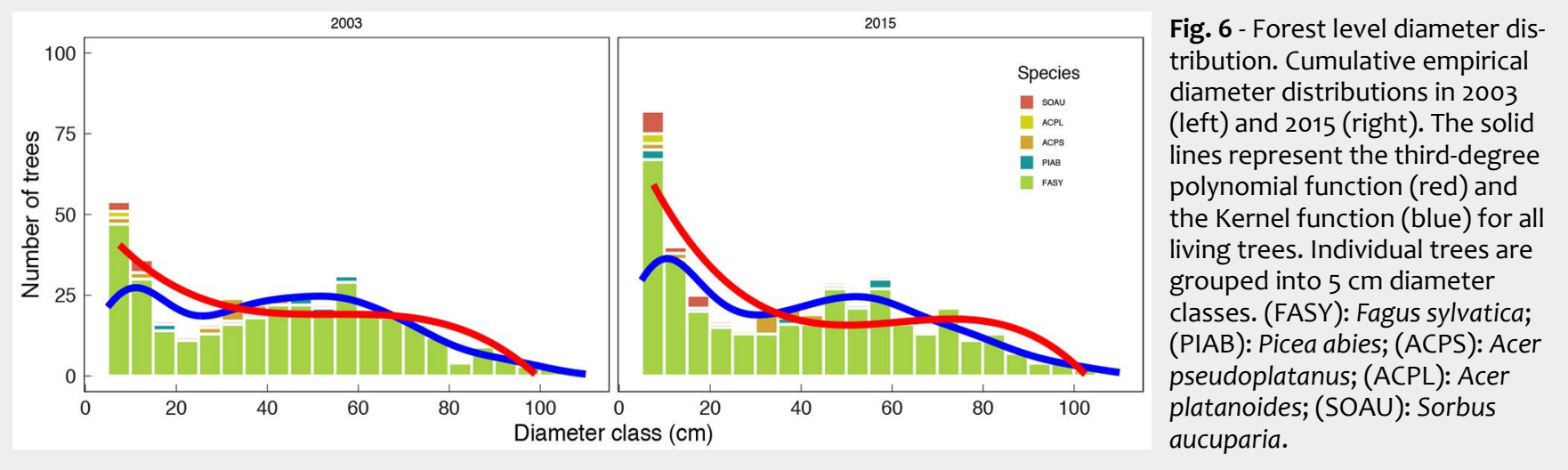

the lowest was on plot $A\left(0.19 \%\right.$ year $\left.{ }^{-1}\right)$. Mortality rates were balanced by the turnover of new tree generations. The generally high recruitment rates during the study period varied among plots; the highest observed densities were on plots $C$ and $E$. The most abundant species in the recruitment layer ( 5 to $20 \mathrm{~cm} \mathrm{DBH)}$ ) was F. sylvatica; $P$. abies, A. platanoides, and S. aucuparia were also present in low densities.

Live tree diameter distribution of the study forest was dominated by F. sylvatica across all diameter classes. Most plots consisted of $F$. sylvatica in the upper canopy with $P$. abies in the mid-canopy, and other species were most common in the lower canopy. The change in the forest level diameter distribution between 2003 and 2015 reflected a convergence to a rotated sigmoid shape (Fig. 6). The plot level diameter distribution displayed a variety of structures in 2003 , often with a tendency towards unimodal distributions, although the reverse J-shaped form was the best fit for study plot $C$. Over time, the rotated sigmoid curves were evident in most plots $(B$, $C, D, E, F)$ in 2015. The other plots $(A, G, H)$ remained stable over time and they had unimodal shapes (see Fig. S2 in Supplementary material). Moreover, the changes were not significant for any of the plots over time (Tab. S2). Size structure was adequately predicted by the third-degree polynomial function, and it proved to be a better fit than the Kernel function.

\section{Discussion}

\section{Current forest structure}

The core zones of the Jizera Mountains Beech Forest Reserve are composed of relatively structurally heterogenous forests. They contain many large and old trees, multilayered canopies, and high variation in tree size and age, all structural characteristics typically associated with old-growth forests (Bauhus et al. 2009). The structural attributes were comparable with other abandoned European beech-dominated forest reserves or primary old-growth forests in Europe (Tab. 4). With the exception of lower dead wood volumes, which are undergoing an accumulation process, the other structural parameters were within the ranges reported by other studies.

The importance of disturbances in dead wood dynamics is well documented (Christensen et al. 2005, Meyer \& Schmidt 2011, Meigs et al. 2017). Each disturbance type has characteristic frequency and intensity patterns, which produces important differences in the spatial and temporal distribution of dead wood. Natural disturbance regimes in European temperate deciduous forests are characterized by mixed disturbance severity regimes, a combination of frequent, small-scale events, and occasional moderate to high-severity events, predominantly caused by storms and drought (Drössler \& Von Lüpke 2005, Trotsiuk et al. 2012, Nagel et al. 2014). Mixed disturbance severity regimes tend to generate irregular inputs of dead wood, with a wide range of sizes, shapes, and decay classes present (Christensen et al. 2005). Christensen et al. (2005) reported an average of $132 \mathrm{~m}^{3} \mathrm{ha}^{-1}$ of dead wood for primary and long-established European beech-dominated forest reserves. Burrascano et al. (2013) observed higher dead wood quantities (mean $=193$ $\left.\mathrm{m}^{3} \mathrm{ha}^{-1}\right)$ in a European dataset of old-

Tab. 4 - Structural data for old-growth European beech-dominated forests. (1): This study (Jizera Mountains Beech Forest); (2): Král et al. 2010 (Zofín); (3): Holeksa et al. 2009 (Hrončecký grún); (4): Kucbel et al. 2010 (Stužica); (5): Paluch 2007 (Labowiec); (6): Commarmot et al. 2005 (Uholka); (7): Keren et al. 2014 (Janj); (8): Motta et al. 2011 (Lom); (9): Commarmot et al. 2005 (Sihlwald); (10): Motta et al. 2015 (Ludrin); (11): Burrascano et al. 2013 (mean for old-growth European beech-dominated forests); (12): for the study period 2001-2010; (13): standing and lying dead wood. Bedrock: (gr) granite; (an) andesite; (fl) flysch; (li) limestone. Soils: (ca) cam bisols; (po) podzols; (re) rendzina. ( $\infty$ ): Considered as a primary forest; (Qmd): Quadratic mean diameter.

\begin{tabular}{|c|c|c|c|c|c|c|c|c|c|c|c|c|}
\hline \multirow{2}{*}{ Variable } & \multirow{2}{*}{ Status } & \multicolumn{11}{|c|}{ Country } \\
\hline & & $\mathrm{CZ}^{1}$ & $\mathrm{CZ}^{2}$ & $\mathrm{SK}^{3}$ & $\mathrm{SK}^{4}$ & $\mathrm{PL}^{5}$ & $U^{6}{ }^{6}$ & $\mathrm{BA}^{7}$ & $B A^{8}$ & $\mathrm{CH}^{9}$ & $\mathrm{IT}^{10}$ & $\mathrm{EU}^{11}$ \\
\hline Last management & - & 1960 & 1882 & $\infty$ & $\infty$ & 1957 & $\infty$ & $\infty$ & 1956 & 1995 & 1962 & - \\
\hline Altitude (m a.s.l.) & - & 671 & 780 & 890 & 1075 & 900 & 750 & 1330 & 1386 & 650 & 1300 & - \\
\hline Bedrock & - & gr & gr & an & $\mathrm{fl}$ & $\mathrm{fl}$ & fl, li & li & li & - & li & - \\
\hline Soils & - & ca, po & ca, po & $\mathrm{ca}$ & $\mathrm{ca}$ & $\mathrm{ca}$ & - & ca, re & re & $\mathrm{ca}$ & $\mathrm{ca}$ & - \\
\hline Age (years) & - & 196 & 169 & - & - & - & 150 & - & - & 150 & - & - \\
\hline Basal area $\left(\mathrm{m}^{2} \mathrm{ha}^{-1}\right)$ & Living & 35.5 & 40.9 & 41.8 & $38.2^{12}$ & 36.3 & 38.5 & 66.7 & 47.1 & 30.7 & 45.1 & 39.9 \\
\hline Qmd (cm) & Living & 47.1 & 50.3 & 46.8 & 38.1 & - & 47.3 & 40.6 & 35.0 & 38.9 & 27.8 & 64.9 \\
\hline \multirow[t]{3}{*}{ Density (trees ha ${ }^{-1}$ ) } & Living & 204 & 206 & 243 & 336 & - & 219 & 516 & 489 & 259 & 741 & 447 \\
\hline & Living 50 & 72 & - & - & - & 73 & - & 115 & 99 & - & 52 & 94 \\
\hline & Living 80 & 17 & - & 6 & 12 & - & 21 & 42 & 18 & - & 0 & - \\
\hline \multirow[t]{3}{*}{ Volume $\left(\mathrm{m}^{3} \mathrm{ha}^{-1}\right)$} & Living & 558 & 695 & 724 & 560 & 543 & 770 & 1215 & 763 & 524 & 533 & - \\
\hline & Standing dead & 32 & - & 25 & - & - & - & 80 & 91 & - & 8 & - \\
\hline & Lying dead & 36 & $202^{13}$ & 281 & 133 & $383^{13}$ & 111 & 307 & 236 & $8^{13}$ & 70 & $193^{13}$ \\
\hline Dead/ living ratio (\%) & & 14.0 & 22.3 & - & 23.7 & - & 13.0 & - & 42.9 & 1.4 & - & - \\
\hline
\end{tabular}


growth forests. Other studies of European beech-dominated forests indicate a natural range of 78 to $387 \mathrm{~m}^{3}$ ha $^{-1}$ (Tab. 4). In Poland, Paluch (2007) observed more than $380 \mathrm{~m}^{3} \mathrm{ha}^{-1}$ of dead wood in the Labowiec Forest Reserve, which was similar to findings from the Janj Forest Reserve in Bosnia and Herzegovina (Keren et al. 2014). In our study, forests with no management for more than 50 years had from 23 to $133 \mathrm{~m}^{3}$ ha $^{-1}$ of dead wood, which is much lower than reported in other studies. Based on the dead to live wood ratio, the observed average value of $14 \%$ was lower than the mean ratio of $21 \%$ for recently-established mountain forest reserves (Christensen et al. 2005). According to a review by Burrascano et al. (2013), our plots fall in the lower part of the range (6-89\%). This pattern is likely related to the more recent soft silvicultural practices (targeted tree gridling, dead wood removal, or understory thinning). On average, standing dead trees represented $36 \%$ of the dead wood recorded, but the proportion varied among plots (from 10 to $71 \%$ ). This was consistent with the percentage of standing dead wood in other old-growth beech-dominated forests, which ranged from 16 to $47 \%$ (Christensen et al. 2005, Vandekerkhove et al. 2009). The high volume of standing dead trees on plot $\mathrm{G}$ was likely due to the higher abundance of coniferous trees, which are generally larger and their decay slower than most deciduous trees (Peterken 1996). All dead wood decay classes were found among the study sites, but the most advanced class (5) was relatively infrequent. This is likely associated with the past silvicultural practices, which likely reduced overall mortality and dead wood inputs (Lombardi et al. 2010). Some studies have suggested that in the absence of major disturbances, dead wood accumulation in managed forests with no management is a slow process (Vandekerkhove et al. 2009, Meyer \& Schmidt 2011). Peterken (1996) suggested that accumulation of near natural volumes of dead wood could occur within a century. Comparing our results to dead wood stocks from primary oldgrowth forests or reserves abandoned for more than 100 years suggests that our studied forest reserve is at the beginning of a long process of dead wood accumulation (Korpel 1995, Christensen et al. 2005, Meyer \& Schmidt 2011). The retention of dead wood as well as artificial creation of dead wood have been identified as the key approaches to successful dead wood management in forests where the aim is to maintain biodiversity (Vítková et al. 2018).

Living tree density and basal area were also comparable with other studies of oldgrowth European beech-dominated forests. According to a review by Burrascano et al. (2013), the mean values of basal area and stem density were higher than the values reported in our study. Our plots had a higher quadratic mean diameter $(47.1 \mathrm{~cm})$ compared to other studies from Europe
(Commarmot et al. 2005, Holeksa et al. 2009, Kucbel et al. 2010, Motta et al. 2011, Keren et al. 2014, Motta et al. 2015); however, Burrascano et al. (2013) reported slightly higher values (mean of $64.9 \mathrm{~cm}$ ) within old-growth European beech-dominated forests. The presence of large trees is considered one of the most important features of old-growth forests. Large F. sylvatica trees play a unique and critical role in supporting diversity of other organisms, such as birds (Czesczewik et al. 2015) and lichens (Hofmeister et al. 2016). Burrascano et al. (2013) reported a minimum threshold of large tree density for old-growth forests at a global scale (30 trees with $\mathrm{DBH} \geq 50$ $\mathrm{cm}$ ), which was observed in our study, but the mean value for European beech-dominated forests is considerably higher. Frequency of larger trees with $\mathrm{DBH} \geq 80 \mathrm{~cm}$ was similar to the values found in other old-growth European beech-dominated forests.

Tree age analysis revealed that the age distribution was multimodal (Fig. S1 in Supplementary material), a pattern commonly found in old-growth beech-dominated forests in Central Europe (Korpel 1995, Trotsiuk et al. 2012). Four recruitment peaks were evident around 1770, 1800-1810, 185070 , and 1960. The number of old trees in our sample was relatively low, so some of the oldest recruitment periods, such as 1770 to 1810 , were difficult to interpret. The longer frequent recruitment period from 1850 to 1870 has also been observed in other Bohemian (Zofín) and Carpathian (Uholka) beech-dominated forest reserves; a higher frequency of strong windstorms has been identified during this period for the region (Trotsiuk et al. 2012, Samonil et al. 2013). The obvious rise in tree recruitment after 1960 can be linked to the mortality of older trees; as older cohorts begin dying, recruitment of a new generation of trees begins. Cautiously, we cannot exclude limited historical human impact in this area that may have influenced recruitment rates. The age distribution also helped explain the sigmoid form of the diameter distribution (Fig. 6); it displayed a more or less pronounced peak in the midsize diameters (Trotsiuk et al. 2012). At least one $F$. sylvatica more than 250 years old was found, but that is younger than the oldest tree (409 years old) previously reported for the Czech Republic (Cada 2014). According to Di Filippo et al. (2017), the maximum and mean age of the three to five oldest trees are good indicators to evaluate old-growth status. Thus, the observed plot mean age of the oldest trees (196 years) demonstrated a characteristic feature of studied old-growth forests, a period when the mean canopy age is at least half the maximum lifespan of the dominant tree species (Trotsiuk et al. 2012). The oldgrowth status of a stand can also be characterized by high variability in tree ages within a given diameter class (Fig. 4), which reflects the complex dynamics of un- even-aged forests (Piovesan et al. 2005, Trotsiuk et al. 2012, Di Filippo et al. 2017).

\section{Changes in forest structural characteristics}

Our study highlighted the changes of oldgrowth features over time since the last forest management interventions; most notably, the density of very large trees, structural diversity, and diameter structure. The U-shaped mortality pattern is characteristic of old-growth forests. Indeed, the relatively high numbers of recruited trees demonstrate the dynamics of the natural regeneration process.

The greater change over time was observed in the density of large living trees with $\mathrm{DBH} \geq 80 \mathrm{~cm}$; changes in the density of smaller trees $(\mathrm{DBH} \geq 50 \mathrm{~cm})$ did not increase as much. Variability in living stem density between measurements was twice as high as that of basal area, as indicated by the relatively high change in stem numbers observed in the lower tree layers ( 5 to $20 \mathrm{~cm} \mathrm{DBH}$ ). The increased basal area could also be interpreted as another indicator of the changes towards more natural forest structures, as harvesting activities in managed forests typically prevent stand basal area from reaching such high values (Heiri et al. 2009). Also, average temporal changes of structural indices showed slight increases (Fig. 2). The DBH differentiation, expressed as the Gini coefficient, was similar to values observed in unmanaged forests of the Carpathians (Pach \& Podlaski 2015). Our results reflect the general pattern that even-aged forests are more homogenous than uneven-aged forests, as suggested by Sterba \& Zingg (2006). The highest Gini indices were found within mixed uneven-aged plots, and pure evenaged plots, which were relatively homogenous, had the lowest Gini indices. Large tree size diversity may ensure a wide range of habitats and provide higher levels of biodiversity in forest ecosystems (Pach \& Podlaski 2015, Kozák et al. 2018).

The diameter structure of the study forest changed over time to a typical rotated sigmoid pattern. Changes in tree numbers were most evident in the smallest diameter classes compared to 2003. The higher number of trees frequently found in the midsize diameters range elucidates a common trend towards a rotated sigmoid diameter distribution. The diameter structures of individual plots indicated variability at the beginning of the study period. Most plots converged towards a rotated sigmoid diameter distribution over time, even the plot with reverse J-shaped diameter structure. In a few plots the diameter structure did not change substantially and they reflected a unimodal structure at the end of the study period. The rotated sigmoid curve of diameter distribution is commonly observed in old-growth forests dominated by F. sylvatica (Westphal et al. 2006, Alessandrini et al. 2011, Trotsiuk et al. 2012). Various studies from North America have also 
reported diameter distributions of a rotated sigmoid form for various mixed-species forests (Goff \& West 1975, Lorimer et al. 2001). Westphal et al. (2006) indicated three main mechanisms, including infrequent disturbance events, mortality, and nonlinear diameter growth rates, which likely explain the rotated sigmoid structure. A mixed disturbance severity regime and associated regeneration can create discontinuous and unbalanced diameter structures. Non-constant mortality rates with a lower mortality rate for all trees that successfully reached the upper canopy level and increased mortality rates for very large trees results in mid-size peaks in diameter distributions. The third factor that drives the development of a rotated sigmoid curve is a positive relationship between diameter increment and stem size (Westphal et al. 2006). The empirical diameter distributions were most precisely predicted by a third-degree polynomial function, which is commonly used to model diameter distributions (Westphal et al. 2006).

The U-shaped mortality trend with minimum mortality rates in the midsize classes corresponded to the current diameter structure that appeared to be converging towards a rotated sigmoid curve (Fig. 6). Complete U-shaped mortality has been reported in several old-growth beech-dominated forests throughout Europe (Alessandrini et al. 2011, Hülsmann et al. 2016). Larger trees are more susceptible than medium-sized trees to insect attacks, drought, rot, and mechanical instability during storms (Holzwarth et al. 2013, Hülsmann et al. 2016). The mortality of small-sized trees is mostly attributed to competition, whereby smaller trees have to compete against larger trees for light, water, and nutrients (Adler 1996, Coomes \& Allen 2007). Annual mortality rates for all species were $0.43 \%$ on average, but that is lower than rates (more than $1 \%$ ) reported for other oldgrowth beech-dominated forests in Central Europe (Holzwarth et al. 2013, Hülsmann et al. 2016). Tree mortality rates are typically low in the absence of larger disturbances (Peterken 1996). Together with observed increases in the density of large trees and basal area in our study forest, the increase in mortality is predictable given the forest age. However, the mortality rates are balanced in the turnover of new tree generations, and the stand gradually again advances to the high growth rate stage of development. Species-specific mortality has been suggested to account for contrasting life history strategies, lifespan, competitiveness, and varying responses to abiotic factors (Franklin et al. 1987, Holzwarth et al. 2013).

\section{Conclusions}

Our study of the Jizera Mountains Beech Forest Reserve core area over a 12-year period found persistent transition of the forest towards natural states after more than five decades without management. The study area displayed a variety of oldgrowth characteristics (e.g., density of large, old trees, structural heterogeneity, diameter distribution, and mortality), which is consistent with previously reported studies on primary old-growth forests or reserves that had never been managed or unmanaged for even longer time periods. The impacts of past management are still visible in the low amounts of dead wood, but the reserve is at the beginning of a long process of dead wood accumulation. As forest development progresses, the death of old trees allows for higher recruitment into the understory and it enhances the growth rates of the surviving trees; this pulse in recruitment cycles and dead wood accumulation will continue in the absence of disturbance or management. Although our study is based on a repeated census dataset covering 12 years, this time span is still very short relative to both the longevity of trees and forest succession. The monitoring of secondary oldgrowth forest reserves and maintaining forest ecosystem services will help ensure responsible stewardship for integrative forest management that aims to address ecological, economic, and social issues across entire forests over time.

\section{Acknowledgements}

This study was supported by IGA project (Bo917) financed by the Internal Grant Agency of FFWS CULS in Prague, institutional project "EVA4.0" (CZ.02.1.01/0.0/0.0/ 16 019/0000803) and project INTER-COST ( $L \bar{T}$ C17055) financed by Ministry of Education, Youth and Sports of Czech Republic. We especially thank to J. Trešnák for providing all data from his diploma thesis. We would like to thank P. Uzel, M. Trčka, J. Hanousek, M. Matouš, D. Hetešová, F. Chrapan, and S. Komín for assistance in the field. We would also like to thank the Jizera Mountains Protection Landscape Area authorities, especially V. Vršovský, for administrative support. Also, thanks to the anonymous reviewers for their helpful and constructive reviews.

$\mathrm{JL}$ designed the methods, carried out surveys, measurement and analysis, coordinated the research team, developed and wrote the manuscript, RCM performed the language revision and helped to draft the manuscript, VT helped with data analysis, PJ, RB, VC, MM, HM and JSS helped with writing the manuscript, KS, LM, MS helped with the laboratory measurement, MS conceived the study and helped to draft the manuscript.

\section{References}

Adler FR (1996). A model of self-thinning through local competition. Proceedings of the National Academy of Sciences USA 93: 99809984. - doi: 10.1073/pnas.93.18.9980

Alessandrini A, Biondi F, Di Filippo A, Ziaco E, Piovesan G (2011). Tree size distribution at increasing spatial scales converges to the rotated sigmoid curve in two old-growth beech stands of the Italian Apennines. Forest Ecology and Management 262: 1950-1962. - doi: 10.1016/j.for eco.2011.08.025

Allen CD, Breshears DD, McDowell NG (2015). On underestimation of global vulnerability to tree mortality and forest die-off from hotter drought in the Anthropocene. Ecosphere 6: 155. - doi: 10.1890/ES15-00203.1

Assmann E (1961). Waldertragskunde. Organische production, Struktur, Zuwachs und Ertrag von Waldbestanden [The principles of forest yield study: studies in the organic production, structure, increment and yield of forest stands]. BLV Verlagsgesellschaft, Munchen, Bonn, Wien, pp. 490. [in German]

Bauhus J, Puettmann K, Messier C (2009). Silviculture for old-growth attributes. Forest Ecology and Management 258: 525-537. - doi: 10.101 6/j.foreco.2009.01.053

Burrascano S, Keeton W, Sabatini F, Blasi C (2013). Commonality and variability in the structural attributes of moist temperate old-growth forests: a global review. Forest Ecology and Management 291: 458-479. - doi: 10.1016/j.for eco.2012.11.020

Cada V (2014). Dlouhovekost buku lesního [The longevity of Fagus sylvatica]. Šumava 4: 10-11. [in Czech]

Cancino J, Von Gadow K (2002). Stem number guide curves for uneven-aged forests - development and limitations. In: "Continuous Cover Forestry" (Von Gadow K, Nagel J, Saborowski J eds). Springer, Netherlands, pp. 163-174.

Christensen M, Hahn K, Mountford EP, Odor P, Standovár T, Rozenbergar D, Diaci J, Wijdeven S, Meyer P, Winter S, Vrška T (2005). Dead wood in European beech (Fagus sylvatica) forest reserves. Forest Ecology and Management 210: 267-282. - doi: 10.1016/j.foreco.2005.02.032 Commarmot B, Bachofen H, Bundziak $Y$, Bürgi A, Ramp B, Shparyk $Y$, Sukhariuk D, Viter R, Zingg A (2005). Structures of virgin and managed beech forests in Uholka (Ukraine) and Sihlwald (Switzerland): a comparative study. Forest Snow and Landscape Research 79: 45-56.

Coomes DA, Allen RB (2007). Mortality and treesize distributions in natural mixed-age forests. Journal of Ecology 95: 27-40. - doi: 10.1111/j.13652745.2006.01179.x

Cybis (2014). CooRecorder and CDendro programs of the CooRecorder. CDendro package, version 7.8. Web site. [online] URL: http:// www.cybis.se/forun/dendro/

Czesczewik D, Zub K, Stanski T, Sahel M, Kapusta A, Walankiewicz W (2015). Effects of forest management on bird assemblages in the Bialowieza Forest, Poland. iForest - Biogeosciences and Forestry 8: 377-385. - doi: 10.3832/ifor12 12-007

Di Filippo A, Biondi F, Piovesan G, Ziaco E (2017). Tree ring-based metrics for assessing oldgrowth forest naturalness. Journal of Applied Ecology 54: 737-749. - doi: 10.1111/1365-2664.127 93

Dove NC, Keeton WS (2015). Structural complexity enhancement increases fungal species richness in northern hardwood forests. Fungal Ecology 13: 181-192. - doi: 10.1016/j.funeco.2014.0 9.009

Drössler L, Von Lüpke B (2005). Canopy gaps in two virgin beech forest reserves in Slovakia. 
Journal of Forest Science 51: 446-457. - doi: 10.17221/4578-JFS

Duncan R (1989). An evaluation of errors in tree age estimates based on increment cores in Kahikatea (Dacrycarpus dacrydioides). New Zealand Sciences 16: 31-37.

Franklin JF, Shugart HH, Harmon ME (1987). Tree death as an ecological process: the causes, consequences and variability of tree mortality. BioScience 37: 550-556. - doi: 10.2307/1310665

Franklin JF, Spies TA (1991). Ecological definitions of old-growth douglas-fir forests. In: "Wildlife and Vegetation of Unmanaged Douglas-Fir Forests" (Ruggiero LF, Aubry KB, Carey $\mathrm{AB}$, Huff $\mathrm{MH}$ eds). General Technical Report, USDA Forest Service, Portland, OR, USA, pp. 6170.

Gini C (1921). Measurement of inequality of incomes. The Economic Journal 31: 124-126. - doi: $10.2307 / 2223319$

Goff FG, West D (1975). Canopy-understory interaction effects on forest population structure. Forest Science 21: 98-108.

Heiri C, Wolf A, Rohrer L, Bugmann H (2009). Forty years of natural dynamics in Swiss beech forests: structure, composition, and the influence of former management. Ecological Applications 19: 1920-1934. - doi: 10.1890/08-0516.1

Hofmeister J, Hošek J, Malíček J, Palice Z, Syrovátková L, Steinová J, Cernajová I (2016). Large beech (Fagus sylvatica) trees as "lifeboats" for lichen diversity in central European forests. Biodiversity and Conservation 25: 1073-1090. - doi: 10.1007/s10531-016-1106-x

Holeksa J, Saniga M, Szwagrzyk J, Czerniak M, Stasynska K, Kapusta P (2009). A giant tree stand in the West Carpathians - an exception or a relic of formerly widespread mountain European forests? Forest Ecology and Management 257: 1577-1585. - doi: 10.1016/j.foreco.2009.01.0 08

Holzwarth F, Kahl A, Bauhus J, Wirth C (2013). Many ways to die - partitioning tree mortality dynamics in a near-natural mixed deciduous forest. Journal of Ecology 101: 220-230. - doi: 10.1111/1365-2745.12015

Hülsmann L, Bugmann HKM, Commarmot B, Meyer P, Zimmermann S, Brang P (2016). Does one model fit all? Patterns of beech mortality in natural forests of three European regions. Ecological Applications 26: 2463-2477. - doi: 10.100 2/eap.1388

IFER (2008). Field-Map technology, version 8. IFER-Monitoring and Mapping Solution Ltd., Web site. [online] URL: http://www.fieldmap. com/

Keeton WS (2006). Managing for late-successional/old-growth characteristics in northern hardwood-conifer forests. Forest Ecology and Management 235: 129-142. - doi: 10.1016/j.for eco.2006.08.005

Keren S, Motta R, Govedar Z, Lucic R, Medarevic $M$, Diaci J (2014). Comparative structural dynamics of the Janj mixed old-growth mountain forest in Bosnia and Herzegovina: are conifers in a long-term decline? Forests 5: 1243-1266. doi: $10.3390 / \mathrm{f} 5061243$

Kozák D, Mikoláš $M$, Svitok $M$, Bače R, Paillet $Y$, Larrieu L, Nagel TA, Begovič K, Cada V, Diku A, Frankovič M, Janda $\mathrm{P}$, Kameniar $\mathrm{O}$, Keren $\mathrm{S}$, Kjučukov P, Lábusová J, Langbehn T, Málek J,
Mikac S, Morrisey RC, Nováková MH, Schurman JS, Svobodová K, Synek M, Teodosiu M, Toromani $E$, Trotsiuk V, Vítková L, Svoboda $M$ (2018). Profile of tree-related microhabitats in European primary beech-dominated forests. Forest Ecology and Management 429: 363-374. doi: 10.1016/j.foreco.2018.07.021

Knorn J, Kuemmerle T, Radeloff VC, Szabo A, Mindrescu M, Keeton WS, Abrudan I, Griffiths P, Gancz V, Hostert P (2012). Forest restitution and protected area effectiveness in post-socialist Romania. Biological Conservation 146: 204212. - doi: 10.1016/j.biocon.2011.12.020

Král K, Janík D, Vrška T, Adam D, Hort L, Unar P, Samonil P (2010). Local variability of stand structural features in beech dominated natural forests of Central Europe: implications for sampling. Forest Ecology and Management 260: 2196-2203. - doi: 10.1016/j.foreco.2010.09.020 Korpel S (1995). Die Urwalder der Westkarpaten [The old-growth forests of Western Carpathians]. Gustav Fischer Verlag, Stuttgart, Austria, pp. 310. [in German]

Kucbel S, Jaloviar P, Saniga M, Vencurik J, Klimaš $\checkmark$ (2010). Canopy gaps in an old-growth firbeech forest remnant of Western Carpathians. European Journal of Forest Research 129: 249259. - doi: 10.1007/s10342-009-0322-2

Lachat T, Bütler R (2009). Identifying conservation and restoration priorities for saproxylic and old-growth forest species: a case study in Switzerland. Environmental Management 44: 105-118. - doi: 10.1007/s00267-009-9281-0

Leak WB (1964). An expression of diameter distribution for unbalanced, uneven-aged stands and forests. Forest Science 10: 39-50.

Lombardi F, Chirici G, Marchetti M, Tognetti R, Lasserre B, Corona P, Barbati A, Ferrari B, DiPaolo S, Giuliarelli D, Mason F, lovino D, Nicolaci A, Bianchi L, Maltoni A, Travaglini D (2010). Deadwood in forest stands close to oldgrowthness under Mediterranean conditions in the Italian Peninsula. Italian Journal of Forest and Mountain Environments 65: 481-504. - doi: 10.4129/ifm.2010.5.02

Lorimer CG, Dahir SE, Nordheim EV (2001). Tree mortality rates and longevity in mature and oldgrowth hemlock-hardwood forests. Journal of Ecology 89: 960-971. - doi: 10.1111/j.1365-2745.20 01.00619.x

Meigs GF, Morrissey RC, Bače R, Chaskovskyy O, Cada V, Després T, Donato CD, Janda P, Lábusová J, Seedre $M$, Mikoláš $M$, Nagel TA, Schurman JS, Synek M, Teodosiu M, Trotsiuk V, Vítková L, Svoboda M (2017). More ways than one: mixed-severity disturbance regimes foster structural complexity via multiple developmental pathways. Forest Ecology and Management 406: 410-426. - doi: 10.1016/j.foreco.2017.07.051 Meyer HA (1952). Structure, growth, and drain in balanced uneven-aged forests. Journal of Forestry 52: 85-92.

Meyer P, Schmidt M (2011). Accumulation of dead wood in abandoned beech (Fagus sylvatica L.) forests in northwestern Germany. Forest Ecology and Management 261: 342-352. - doi: 10.1016/j.foreco.2010.08.037

Motta R, Berretti R, Castagneri D, Dukić V, Garbarino M, Govedar Z, Lingua E, Maunaga Z, Meloni F (2011). Toward a definition of the range of variability of central European mixed
Fagus-Abies-Picea forest Lom (Bosnia and Herzegovina). Canadian Journal of Forest Research 41: 1871-1884. - doi: 10.1139/x11-098

Motta R, Garbarino M, Berretti R, Meloni F, Nosenzo A, Vacchiano G (2015). Development of old-growth characteristics in uneven-aged forests of the Italian Alps. European Journal of Forest Research 134: 19-31. - doi: 10.1007/s10342014-0830-6

Nagel T, Svoboda M, Kobal M (2014). Disturbance, life history traits, and dynamics in an old-growth forest landscape of southeastern Europe. Ecological Applications 24: 663-679. doi: 10.1890/13-0632.1

Pach M, Podlaski R (2015). Tree diameter structural diversity in Central European forests with Abies alba and Fagus sylvatica: managed versus unmanaged forest stands. Ecological Research 30: 367-384. - doi: 10.1007/s11284-014-1232-4

Paluch JG (2007). The spatial pattern of a natural European beech (Fagus sylvatica L.)-silver fir (Abies alba Mill.) forest: a patch-mosaic perspective. Forest Ecology and Management 253: 161-170. - doi: 10.1016/j.foreco.2007.07.013

Parviainen J, Bucking $\mathrm{W}$, Vandekerkhove K, Schuck A, Päivinen R (2000). Strict forest reserves in Europe: efforts to enhance biodiversity and research on forests left for free development in Europe (EU-COST-Action E4). Forestry 73: 107-118. - doi: 10.1093/forestry/73.2.107 Parviainen J, Schuck A, Bozzano M, Estreguil C, Koskela J, Lier M, Spielmann M, Van Brusselen J (2011). Criterion 4: maintenance, conservation and appropriate enhancement of biological diversity in forest ecosystems. In: "State of Europe's Forests 2011, Status and Trends on Sustainable Forest Management in Europe". FOREST EUROPE, UNECE and FAO, Aas, Norway, pp. 65-97. [online] URL: https://www.foresteu rope.org/documentos/State_of_Europes_Fores ts_2011_Report_Revised_November_2011.pdf Persiani AM, Lombardi F, Lunghini D, Granito VM, Tognetti R, Maggi O, Pioli S, Marchetti M (2015). Stand structure and deadwood amount influences saproxylic fungal biodiversity in Mediterranean mountain unmanaged forests. iForest - Biogeosciences and Forestry 9: 115-124. - doi: 10.3832/ifor1304-008

Peterken GF (1996). Natural woodland: ecology and conservation in northern temperate regions. Cambridge University Press, Cambridge, UK, pp. 540.

Petráš R, Pajtík J (1991). Sústava česko-slovenských objemových tabuliek drevín [Forest tree volume tables of the CSFR]. Lesnický Casopis 31: 323-333. [in Czech]

Piovesan G, Di Filippo A, Alessandrini A, Biondi F, Schirone B (2005). Structure, dynamics and dendroecology of an old-growth Fagus forest in the Apennines. Journal of Vegetation Science 16: $13-28$.

Rinntech (2010). TSAP-WinTM: time series analysis and presentation for dendrochronology and related applications, version $4.69 \mathrm{~h}$. Web site. [online] URL: http://www.rinntech.com/ RStudio Team (2016). RStudio: integrated development for R. RStudio, version 1.0.136, web site. [online] URL: http://www.rstudio.com/ Samonil P, Dolezelová P, Vašíčková I, Adam D, Valtera M, Král K, Janík D, Sebková B (2013). Individual-based approach to the detection of 
disturbance history through spatial scales in a natural beech-dominated forest. Journal of Vegetation Science 24: 1167-184. - doi: 10.1111/jvs. 12025

Sheil D, May RM (1996). Mortality and recruitment rate evaluations in heterogenous tropical forests. Journal of Ecology 84: 91-100. - doi: 10.2307/2261703

Sippola AL, Renvall P (1999). Wood-decomposing fungi and seed tree cutting: a 40 year prespective. Forest Ecology and Management 115: 183-201. - doi: 10.1016/S0378-1127(98)00398-3

Sterba H, Zingg A (2006). Abstandsabhängige und abstandsunabhängige Bestandesstrukturbeschreibung [Distance-dependent and distance-independent structure description]. Allg Forst-Jadztg 177: 169-176. [in German]

Stokes MA, Smiley TL (1986). An introduction to tree-ring dating. University of Chicago Press, Chicago, IL, USA, pp. 73.

Tolasz R, Miková T, Valerianová A, Voženílek V (2007). Klimatický atlas Ceska [Climate atlas of Czechia]. Ceský hydrometeorologický ústav a Palckého Univerzita v Olomouci, Praha, olomouc, Czech Republic, pp. 256. [in Czech]

Trešnák J (2004). Produkční dusledky ponechání části lesa spontánnímu vývoji v oblasti Jizerskohorských bučin [The production of forest left to spontaneous development in the Jizera beech forest]. Diplomová práce, Fakulta lesnická a environmentální, CZU v Prague, Czech Republic, pp. 51. [in Czech]

Trotsiuk V, Hobi ML, Commarmot B (2012). Age structure and disturbance dynamics of the relic virgin beech forest Uholka (Ukrainian Carpathians). Forest Ecology and Management 265: 181190. - doi: 10.1016/j.foreco.2011.10.042

Vandekerkhove K, De Keersmaeker L, Menke N, Meyer P, Verschelde P (2009). When nature takes over from man: dead wood accumulation in previously managed oak and beech woodlands in North-western and Central Europe. Forest Ecology and Management 258: 425-435. - doi: 10.1016/j.foreco.2009.01.055

Veen P, Fanta J, Raev I, Biris IA, Smidt J, Maes B (2010). Virgin forests in Romania and Bulgaria: results of two national inventory projects and their implications for protection. Biodiversity and Conservation 19: 1805-1819. - doi: 10.1007/ s10531-010-9804-2

Vítková L, Bače R, Kjučukov $P$, Svoboda $M$ (2018). Deadwood management in Central European forests: key considerations for practical implementation. Forest Ecology and Management 429: 394-405. - doi: 10.1016/j.foreco.2018. 07.034

Vrška T, Hort L (2008). Odkdy a proč chráníme samovolné procesy? [Since and do we protect the spontaneous processes?] Lesnická Práce 7: 464-466. [in Czech]

Vysoky J, Jasík M (2015). Pralesov je na Slovensku málo a ani tie nedokážeme efektívne chránit [There is a few old-growth forests in Slovakia and we cannot even protect them]. Tlačová správa, PRALES, o.z., web site. [online] URL: http://www.pralesy.sk/kniznica/aktuality/1 33-pralesov-je-na-slovensku-malo-a-ani-tie-nedo kaeme-efektivne-chrani.html
Westphal C, Tremer N, Von Oheimb G, Hansen J, Von Gadow K, Härdtle W (2006). Is the reverse J-shaped diameter distribution universally applicable in European virgin beech forests? Forest Ecology and Management 223: 75-83. - doi: 10.1016/j.foreco.2005.10.057

Zatloukal V, Beranová J, Holá S, Litschmann P, Vopenka P, Višnák R (2010). Plán péče o Národní prírodní rezervaci Jizerskohorské bučiny na období 2012-2020 [Forest care plan management of the Jizera Mountains Beech Forest Reserve for the period 2012-2020]. Správa CHKO Jizerské hory, Liberec, Czech Republic, pp. 280. [in Czech]

\section{Supplementary Material}

Tab. S1 - Annualized tree mortality and natality rates over 12-year period (20032015) for all species and study plots (A-H).

Tab. S2 - Kolmogorov-Smirnov tests for differences in the plot $(\mathrm{A}-\mathrm{H})$ diameter structure between 2003 and 2015.

Fig. S1 - Decadal age structure of living trees and tree species for all study plots in 2015.

Fig. S2 - Empirical diameter distributions of the study plots (panels A-H) in 2003 (left) and 2015 (right).

Link: Labusova_2702@supplo01.pdf 